\title{
The Revival of Traditional Practices as a Response to Outsiders' Demands: The resurgence of natural dye use in San Juan La Laguna, Guatemala
}

\author{
Heloísa Speranza Modesto and Sandra Niessen
}

\begin{abstract}
The Revival of Traditional Practices as a Response to Outsiders' Demands: The Resurgence of Natural Dye Use in San Juan La Laguna, Guatemala. Over the last two decades increased interest in "natural" products in North America has, along with the banning of Azo dyes in Germany, helped expand market demand for naturally dyed textiles. This paper explores natural dye use among the members of a Mayan women's artisan group in San Juan La Laguna, Guatemala - one of the only Guatemalan groups that was using natural dyes in 2000. It evaluates the artisans' motivations to use natural dyes and the socio-economic impacts of its use. Women control textile and dyeing activity in San Juan and the returns play an important role in complementing household income. The use of natural dyes involves additional knowledge and effort. Because natural dye knowledge is restricted and the market for naturally dyed textiles is unappealing for artisans, the number of artisans who use this technique is limited; this in turn reduces the use of dye-material and market competition.
\end{abstract}

\section{Introduction}

Proyecto Típica, a Tzutujil Mayan women's artisan group in San Juan La Laguna, Guatemala (Figure 1), is among the few in Guatemala that use natural dyes for textile production. The present paper explores the production of naturally dyed textiles in the Guatemalan context, using Proyecto Típica as a case study, with the goal of supplementing the information available about the impact this type of production has on the artisans. It offers a case study of a Guatemalan women's artisan group that has responded to foreign-consumer demands for naturally dyed textiles. The paper provides relevant information about the impacts on artisans and their environments brought about by the use of natural dyes - impacts that should be considered by non-government organizations (NGOs) be- fore they promote natural dyeing techniques. In evaluating this impact, we address: (a) knowledge control among Proyecto Típica's artisans; (b) the production organization and artisans' efforts in naturally dyed textile production; and (c) the sales of Proyecto Típica's textiles, the group's returns and their motivations to continue to use natural dyes in their textile production.

The case study explored in this paper is based on five months of ethnographic fieldwork conducted in Guatemala, from January to May of 2000. The main objective of the research was to evaluate the socio-economic impact of naturally dyed textile production on the members of Proyecto Típica. A total of 27 artisans from Proyecto Típica directly participated in demographic surveys and informal interviews. In addition, a purposive grouping of the Proyecto Típica members was the focus of participatory observation. In order to learn about the use of natural dyes in Guatemala, key informants were used. In the fieldwork a Gender and Development perspective was used, which does not consider women to be an homogeneous category of analysis. In order to guarantee the anonymity of the participants in this investigation, we have adopted

\section{Correspondence}

Heloísa Speranza Modesto and Sandra Niessen, Healthy Dyes Project, Department of Human Ecology, 10839 - 66 Avenue, University of Alberta, Edmonton, T6H 1Y1, Alberta, CANADA. helomodesto@hotmail.com

Ethnobotany Research \& Applications 3:155-166 (2005) 


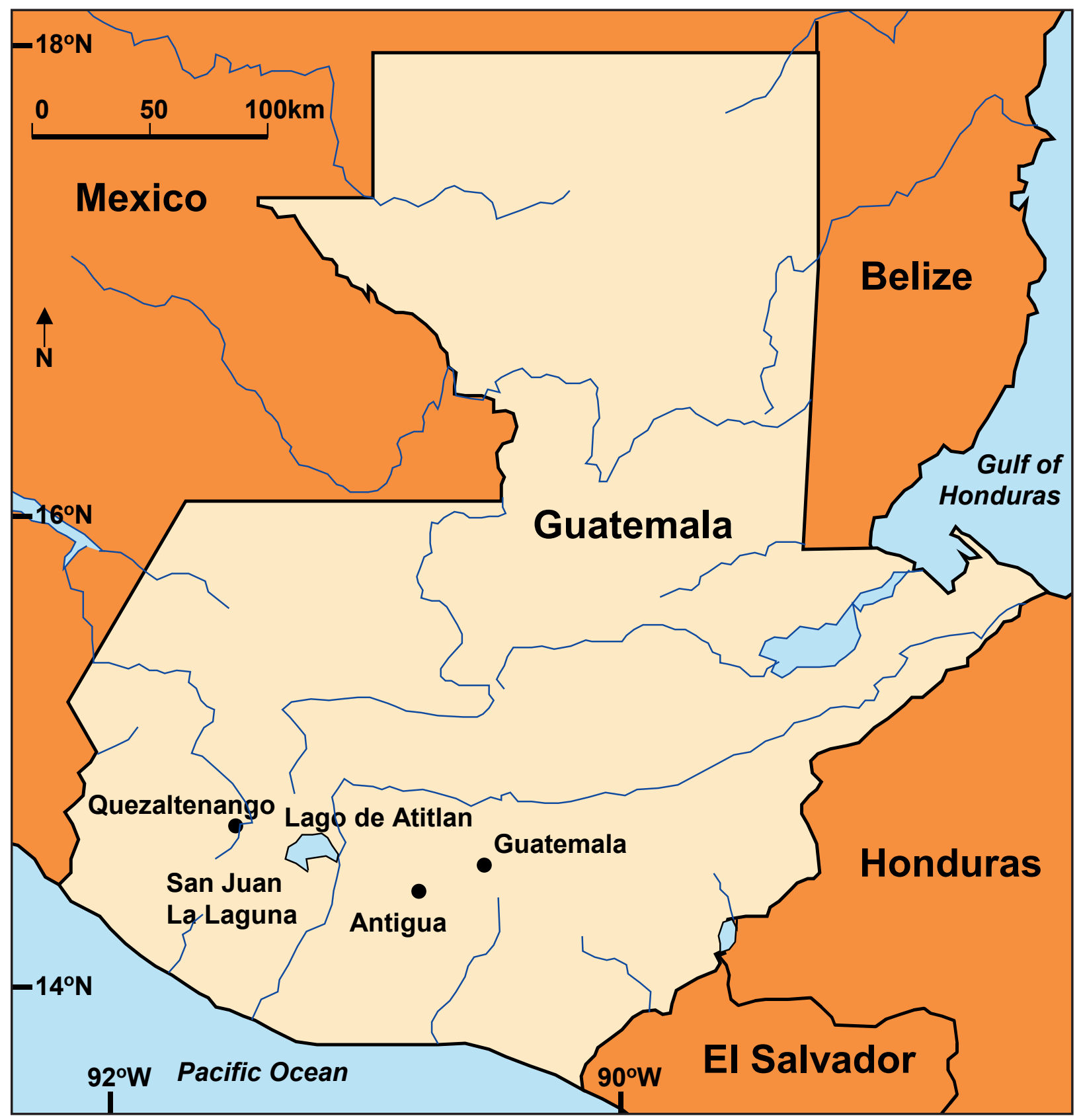

Figure 1. Guatemala with study site in San Juan La Laguna.

pseudonyms for all weavers and weavers' groups mentioned in this paper.

\section{Natural Dyes in Guatemala}

Tourism is the second largest industry in Guatemala after coffee production (Moreno \& Littrell 1998) and Mayan textiles have always played an important role as promotional tools for attracting tourists to Guatemala (Hendrickson 1997, Rouanet 1989). The development of commercial textile production for the tourist market in Guatemala offered an income alternative for the indigenous that would supplement their income and secure their families' subsistence (Nash 1993, Swetnan 1989). With the intensification of commercial textile production, competition increased. The prices of the Guatemalan textiles were continually lowered to appeal to tourists, a fact that was reflected in the low wages received by the artisans. In order to make the textile prices even more competitive, the quality was often reduced. As an alternative, a few producers special- 
Modesto \& Niessen - The Revival of Traditional Practices as a Response to
Outsiders' Demands: Resurgence of natural dye use in San Juan La Laguna

ized in the production of higher-quality textiles intended to meet the demands of a special clientele - a clientele that is willing to pay more for higher quality textiles. Textile producers and retailers in Guatemala associate the use of natural dyes with higher-quality textiles.

Indigo (a plant used for blue dye) and cochineal (an insect that feeds on pear cactus and is used for red dye) were the main commodities in Guatemala before the introduction of coffee and the advent of synthetic dyes (Lara 1988). Natural dyeing techniques were abandoned in the beginning of the twentieth century in Guatemala (Carlsen \& Wenger 1991). According to Racanog (1997), knowledge about natural dyeing techniques has always been a closely guarded secret among the Mayan people. In the last two decades, increased consumer interest in naturally dyed textiles in North America (Buchanan 1990) and the German banning of azo dyes (Hill 1996) have expanded the market demand for naturally dyed textiles. According to Hill (1996), natural dyes attract consumers due to their unique shades, their natural sources, and the assumption that they are environmentally friendly. With the potential market for natural dyes, and since the knowledge about natural dyeing techniques was often partially or entirely forgotten, individual professionals, NGOs and government agencies have facilitated the weavers' return to use of natural dyes in Southern countries (Anderson 1998, LWDP/ WAYANG 1995, Morris 1991, UNDP n.d.). In Guatemala CEDART (Handicraft Design Development and Capacitating Centre) is an NGO that has used international funds to promote the training of 40 artisans in natural dyeing techniques. The promotion of natural dyes has been reported to benefit artisans through:

- Promoting sustainable development, by reducing threats to the physical environment, and increasing artisans' connections with the environment (Aageson 1999, UNDP 1996, LWDP/WAYANG 1995).

- $\quad$ Reviving ethnic traditions and improving textile quality (Anderson 1998, Morris 1991).

- $\quad$ Differentiating textiles in response to a special market demand niche, and increasing artisan returns (Anderson 1998, Morris 1991).

Practices based on traditional knowledge, although intended to promote people's empowerment and lead to more ecologically sustainable practices, are not necessarily ecologically sustainable and socially just (Antweiler 1998). Furthermore, traditional knowledge is not always democratically shared by all members of a community. In contrast to the impression of many people, natural dyeing processes can also harm the environment. Some of the mordants used in the dyeing process contain heavy metals and other environmentally hazardous substances (Dalby 1990, Hill 1996). Moreover, indiscriminate harvesting of wild plants can result in endangered species (Hill 1996). Based on studies of natural dye use in Guatemala, Gould et al. (1998) and Davis (2000) reported that they were unsure about the long-term sustainability of the dye plants extracted for the production of potpourri and textiles in Guatemala. As of 2001, the use of natural dyes in Guatemala was completely oriented to international consumers (Davis 2000, Gould et al. 1998, Modesto 2001). The use of natural dyes is a technique that can illustrate a technological production adaptation "to the combined constraints of the indigenous lifestyle and the external market" (Niessen 1996).

\section{Local Setting}

San Juan La Laguna was founded in 1618 during the solidification of Spanish control in Guatemala, in an area settled by the Tzutujil Maya (Orellana 1984) on the shores of Lake Atitlán, in the departamento (state) of Solalá. The municipality of San Juan has a population of 6380 people, of whom 97 per cent are Tzutujil (Lopez 1997, p. 4). Most people in San Juan La Laguna are landless or own small plots that are not sufficient for household subsistence, thus causing dependence on a cash economy. In San Juan La Laguna, the majority of the people depend on coffee and textile production - the two main sources of cash that allow the local population to avoid migrating to coastal plantations for work (Modesto 2001). Land continues to be the primary means of wealth, and indigenous families from a neighbouring town own the majority of the land that surrounds San Juan. Coffee is San Juan's main agricultural crop and main source of cash - in detriment to agriculture of subsistence. The majority of the population depends on agricultural wage labour, with wages varying from 10 Quetzales during the rainy season, to 25 Quetzales during the dry season when labour demand is very high due to the coffee harvest (in May of 2000, 7.5 Quetzales was equivalent to one American dollar). In this community, one pound of the cheapest corn (the staple local food) costs one Quetzal, and a family of five needs seven pounds of corn a day.

Women in San Juan play an important role in generating income for their households. Textile returns, although much lower than coffee income, play an important role since they represent the only form of income women have at their disposal, while still remaining in their households. Textile activity in San Juan continues to be controlled by women - in contrast to the situation in other communities on Lake Atitlán (Ehlers 1993) - and is based on the use of the back-strap loom, as used by Mayan ancestors. Textile wages complement agricultural wages and agriculture of subsistence. Textile production is one of the only means of income available during the coffee off-season, and is sometimes the only source of cash where women are the heads of the households.

\section{Proyecto Típica}

Proyecto Típica, a Tzutujil Mayan women's artisan group, has been using natural dyes for the past decade. Proyecto Típica was initiated by a local textile entrepreneur and a 
group of artisans who work for her as piece-workers. The municipality officially recognized this group in 1989, and the former entrepreneur - who we will call Carmen - has since become the group's president. Proyecto Típica has received assistance from development agencies and foreign patrons, in the forms of credit, skills training and access to markets, although this assistance has never been on a continuous basis. Regardless of their designation as a project, cooperative or association, artisan groups in San Juan tend to exhibit a hierarchical structure rather than a democratic one (Modesto 2001). Despite a democratic formal structure documented in the project's meeting minutes, Proyecto Típica in practice actually presents a highly vertical hierarchical structure that concentrates all of the decision-making and production-control in Carmen's hands. Carmen has a patron-client relationship with the other members. In the textile production environment in San Juan, one designed for foreign consumers, patronclient relationships are likely to occur. In San Juan, few individuals have knowledge about market channels and market demands, can gain access to the required capital, and possess aesthetic skills - all required factors for success in the international textile market. Moreover, in a typical textile project few members understand how, or have enough confidence, to network with foreign individuals and organizations - to link general members to development agencies, for example. A small minority is knowledgeable of financial institutions where they can request credit, for which they are required to have a minimum amount of capital. Indigenous women who have not been exposed to the outside world are usually hesitant to deal with outside institutions, preferring instead to rely on community creditors (Hermitte 1972). Many local women do not have the minimum capital nor the knowledge and skills possessed by the entrepreneurs, and in weaving find the only means they have to earn an income to ensure their families' survival.

Carmen belongs to a minority of local women who have been exposed to the world outside San Juan, and she has all of the characteristics required to be a patron. Carmen controls knowledge about textile techniques, credit access, market demands and channels, and does all networking with outsiders on behalf of Proyecto Típica. She also owns capital and can qualify for bank credit. She is financially stable, allowing her to invest in materials, pay wages to the other artisans, and wait for indeterminate periods of time to recover her investments - a significant benefit in a capital-uncertain activity such as textile production (Rosebaum \& Goldin 1997). The president decides who does what, and when, while the rest of the women in the group attend to the president's specifications and receive wages as piece-workers. The other artisans in Proyecto Típica do not enjoy secure financial situations, nor do they have similar exposure - as does the president - to outside institutions, and so do not have the opportunity to qualify for institutional credits. These artisans, in the face of sparse local income alternatives, prefer to be loyal to Carmen and accept the small wages from the textile activity in exchange for her support during adverse life situations - a clear patronage system.

\section{Natural Dye Knowledge and Motivation of Artisans}

The use of natural dyes in this group is restricted to the production of textiles for the tourist market. None of the artisans working in Proyecto Típica wears or uses natural dyes for their domestic textiles. From the perspective of these Mayan artisans, acrylic and imported mercerized industrial cotton threads - as opposed to naturally dyed ones - continue to represent the high-quality standard preferred for domestic use. The production of differentiated quality textiles, such as those naturally dyed, requires additional knowledge and capital from the artisans (Jopling 1971) - requirements met by Carmen, who initiated the use of this technique in her group. Carmen is the only member of the group controlling the knowledge regarding the dye-material sources, technical knowledge, and the market channels for naturally dyed textiles. The president was found to have different motivations, labour input and returns than the rest of the artisans in her group. Carmen gave several reasons for her motivation to produce natural dyes. First, the industrially dyed yarn available in the market was of low quality and retailers refused to buy textiles produced with them. Second, "people from far away were getting skin disease due to the use of chemical dyes" - a reference to the German ban on the importation of textiles produced with azo dyes (Hill 1996). Third, Carmen learned that artisans in Salcajá and Santiago Atitlán, also located in the Guatemalan Highlands, were "dyeing with plants", and believed that this technique could differentiate her textiles, helping her access high-end retailers. Based on the above motivations, and using a basic knowledge learned from her grandmother, Carmen mastered the techniques of a broad range of natural dyeing methods. As usual among Mayan dyers (Racanog 1997), Carmen protects the secrecy of the dye plants she uses and the dye-preparation procedures. She strategically restricts all dye collection and preparation to her close family members, fearing that the propagation of her knowledge to other artisans could promote competition for the textiles produced by Proyecto Típica. Through her knowledge about natural dyes, Carmen enjoys prestige from consumers, retail storeowners, and development organizations interested in her experience. She also receives attention from academics, such as myself, interested in the revival of natural dye use. She has refused an offer of 8000 Quetzales (\$1066.00 US dollars) to give natural dye workshops to other indigenous groups. In addition, a store in Antigua asked Carmen to teach a workshop on natural dyeing techniques to tourists, at a rate of 700 Quetzales (about \$95 US dollars) per student. This same store is interested in publishing a booklet about Carmen's natural dyeing techniques, of which Carmen would receive a percentage of the profits. Carmen turned down these opportunities as well. She explained that sharing the knowledge 


\section{Modesto \& Niessen - The Revival of Traditional Practices as a Response to Outsiders' Demands: Resurgence of natural dye use in San Juan La Laguna}

about natural dyes with others would promote competition with Proyecto Típica.

The artisans of this group, working on a piece-wage basis, do not receive any prestige from the use of natural dyes, and expressed different motivations for using natural dyes. The large majority of these artisans were indifferent regarding natural dye use; several of the artisans had only recently learned that the threads provided to them by Carmen were in fact naturally dyed. When asked for their insights regarding the benefits in using natural dyes, 19 out of 27 weavers simply commented on the fact that the colour of the threads does not wash away (i.e., of a better quality). Only eight weavers expressed belief that the natural dyes differentiated the textiles being produced, and that this was the reason Carmen sold more than the other local entrepreneurs and projects. These artisans also commented that the use of natural dyes provided Carmen and themselves with more steady work and better returns than artisans producing lower-quality textiles, but no better than those producing other high-quality textiles.

In Guatemala, while several of the people met during fieldwork were aware of some of the plants that were used by their ancestors as dyes, most people did not have any knowledge about the preparation methods of the dyes. In order for someone to learn to dye, they have to learn by experimenting on their own, or by benefiting from someone else's experience. CEDART has published a manual that briefly describes some of the procedures of natural dyeing (Reiche \& Itzep 1999). However, artisans generally have little formal education and are more likely to learn by experimenting than by reading a manual. The manual, which was based on workshops promoted by the Guatemala NGO, notes this organisation's awareness of, and concern for, the potential environmental hazards of uncontrolled dye preparation and use.

Despite Carmen's efforts to keep her knowledge about natural dye preparation from others, a second group of weavers in San Juan has begun to produce naturally dyed textiles with similar patterns to those produced by Proyecto Típica. Three women members of this group received natural dye training from a consultant working with CEDART. Despite the fact that it has received more support from development agencies, this group was having difficulties selling their textiles during the fieldwork due to the saturation of the high-end market with textiles of similar appearance and quality. The fact that this second group learned of and began to use natural dyes caused increased market competition for Proyecto Típica, and today the two groups compete for the chance to consign their textiles to high-end retail stores and fair trade organizations. The emergence of the second group also increased the competition for local wild natural dye sources that are already scarce in the San Juan region, as discussed below and also noted by Davis (2000).

\section{Efforts Accessing Natural Dyes}

Only members of Carmen's close family participate in accessing and processing dyes, as she has said that she cannot share her secrets with people she does not trust. For the dyeing activities, Carmen counts on the help of her daughter-in-law. Neither Carmen nor her daughter-inlaw are paid on a wage basis. Carmen said that she gives her daughter-in-law an occasional cash contribution when textile sales are good, so that her daughter-in-law will not be tempted to work with other groups and teach others the dyeing techniques. The returns Carmen receives from the work involved in collecting and preparing dyes are paid from net profits from textile sales, or from sales of naturally dyed yarns. The only ones to receive wages for accessing natural dyes are the male collectors - usually Carmen's son-in-law, who has knowledge about dye plants. Carmen's son-in-law brings another male wage labourer to help when collecting dye plants in sites very far from San Juan, and to help him carry back the large bags of dye materials collected.

Carmen accesses natural dyes in different ways depending on where the dye material is found. The dye plants used consist of native wild and cultivated plants (Table 1). Seasons affect the access to native dye plants because, during the rainy season, it is difficult to collect some of the plants used, and during the dry season, many of the trees are too dry and not appropriate for collection. Cultivated plants used for the dye preparation that are also used as condiments, teas, food, or ornaments are easily found in markets throughout Guatemala, while cultivated plants used mainly for dyeing purposes have become more difficult to find. The non-cultivated dye plants used are all native plants of the San Juan region and are found on communal or private land. Some of them are also used for medicinal purposes and/or fuelwood. In the past, these native dye plants were found in the land surrounding San Juan and Carmen used to collect dye materials with the help of her female relatives. As of last year, though, the native dye trees were only found in areas far from San Juan due to the expansion of local coffee plantations. According to local cultural rules, women are not supposed to walk throughout the mountains by themselves. Carmen pays her son-in-law a wage of 30 Quetzales (\$4 US Dollars) per day to collect wild tree bark in the mountains, due to the difficulties involved in accessing these distant sites. She also counts on help from her daughter-in-law for collecting dyes in the San Juan vicinity. During her trips to Solalá, Quetzaltenango and Antigua, Carmen shops and searches for dye materials in the vicinity of these cities and on the roadsides.

Davis (2000) draws attention to the line between sustainable harvesting and over-harvesting of dye plants in cases where natural dye use has increased. The hills that surround San Juan already have had most of the natural veg- 
Table 1. Plants Used in the Preparation of Dyes in San Juan La Laguna, Guatemala.

\begin{tabular}{|c|c|c|c|c|}
\hline $\begin{array}{l}\text { Local Common } \\
\text { Name }\end{array}$ & $\begin{array}{l}\text { English Common } \\
\text { Name }\end{array}$ & Scientific Name ${ }^{1}$ & $\begin{array}{l}\text { Part Used for Dye } \\
\text { Preparation }\end{array}$ & $\begin{array}{l}\text { Dye Colour } \\
\text { Produced }\end{array}$ \\
\hline Achiote & Annato & Bixa orellana L. & Seeds & Red \\
\hline Aguacate & Avocado & Persea americana Mill. & Seed, bark and leaves & Green \\
\hline Barba de Léon & & Cuscuta sp. & Vines & Brown/orange \\
\hline Café & Coffee & Coffea arabica L. & Coffee pulp & Light brown \\
\hline Chilca $^{2}$ & & Senecio sp. & Fruits & Greenish yellow \\
\hline Coco & Coconut & Cocus nucifera L. & Fruit's husks & Brownish yellow \\
\hline Encino $^{2}$ & Oak & Quercus sp. & Bark & Brownish \\
\hline Eucalipto & Eucaliptus & Eucalyptus sp. & Leaves and bark & Light yellow \\
\hline Flor de Muerto ${ }^{2}$ & Marigold & Chrysanthemum sp. & Flower & Orange and yellow \\
\hline Granada & Pomogranate & Punica granatum L. & Fruits & Brownish/mordant \\
\hline Ilamo/Aliso $^{2}$ & Alder & Alnus sp. & Bark & Brownish \\
\hline Nance & & Byssonimia sp. & Bark & Brownish \\
\hline Rosa Jamaica & Hibiscus & Hibiscus sp. & Dried flowers & Pink and purple \\
\hline Sacatinta & & Jacobina spicigera Schl. & Leaves and stems & Blue and green \\
\hline
\end{tabular}

1. All plants were identified by the authors.

2. Wild native plants.

etation cut down for the implementation of coffee and corn plantations. In addition to this, the reduced areas of natural vegetation are the last resources used by the local population for harvesting fuelwood. During the fieldwork, two people were interviewed in the San Juan area who owned plots where wild dye trees were found. They noted that the demand for encino and ilamo tree bark, both native and noncultivated trees, had increased in the last few years. One owner said that, initially, a lone collector from Proyecto Típica would collect tree bark on his plot every year, but now there are at least seven collectors. This could be a consequence of the new textile group that also started to produce naturally dyed textiles in San Juan, and maybe individuals who want to experiment with natural dyes. They reported that the sale of bark from both trees is an alternative to their usual practice of cutting these trees down to be sold as fuelwood. However, they said that so far, the profit from bark sales is inferior to the returns received from timber sales.

Davis (2000) concluded that Proyecto Típica artisans could not grow natural dye plants because the group's artisans were landless. However, based on the information collected about Proyecto Típica household land ownership, more than half of Proyecto Típica members do own some land, where they grow mostly coffee and/or corn. Moreover, Proyecto Típica's president - the only member of Proyecto Típica who would directly benefit from growing dye plants - is one of the largest landowners in San Juan, and still is not interested in growing dye trees or plants. We attribute this lack of interest to the fact that the land is being used for coffee production, which is a commodity that gives higher returns than dye plants. In addition, although coffee trees in San Juan are grown in shaded areas, the trees used as dye sources (with the exception of avocado) are not suited for cultivation in association with coffee. It could also be that Carmen - although interested in growing dye plants - does not have decision-making control over her household land. In the local context, male household members usually control the land.

\section{Efforts Preparing Natural Dyes and Dyeing}

Carmen travels to Salcajá to access threads, and to other different regions to access the different dye materials she uses. Once all of the materials needed for the dye preparation are gathered, the preparation of natural dyes still involves physically demanding tasks. These include seed and leaf grinding with the Mayan stone mortar and pestel, the opening of seedpods, and the cutting of tree bark and stems into small pieces. To illustrate the hard work involved in dye preparation, we describe the preparation of a blue dye prepared with sacatinta quilete (Jacobina spicigera Schl.), a dye plant that is still occasionally cultivated in Guatemala. The leaves and stems from the sacatinta produce a blue dye and continue to be used in Guatemala to fix and improve the colours of synthetic dark blues. To access this dye, Carmen has to travel five hours each way by bus. The preparation of this dye involves two days of leaf and stem grinding, and five additional days of fermentation during which Carmen and her daughter-in-law frequently stir the vat vigorously for half an hour each day. Washed yarn skeins of half a pound are dipped into the green vat and then hung on a wire. The dye turns blue when it is oxidized from contact with the air, adhering to yarns. These yarn skeins are 


\section{Modesto \& Niessen - The Revival of Traditional Practices as a Response to Outsiders' Demands: Resurgence of natural dye use in San Juan La Laguna}

transferred to a mordant vat prepared with water, pomegranate and cooking salt. In preparing the mordant, both dyers had to work over the open fire for more than one hour. Afterwards, the yarn skeins are removed from the hot mordant solution and vigorously washed in cold water by Carmen's daughter-in-law, who reported the temperature shock to be very hard on her hands. While preparing the mordant, the intense smoke hurt the women's eyes. When some of the sacatinta splashed into the face of Carmen's daughter-in-law, her eyes were sore for several days. Moreover, Carmen and her daughter-in-law worked without gloves, dipping their hands into the sacatinta vat to remove the skeins of yarn and squeeze the skeins. In the days after dyeing, both women had several sore, dark burn spots on their hands.

The preparation of natural dyes and the actual dyeing of threads is a long, labour-demanding process, as opposed to the dyeing process with synthetic dyes, which can be completed in two hours. In the week working with the sacatinta, 20 pounds of yarn were dyed - an amount sufficient to produce six single-colour wide shawls (70 per $230 \mathrm{~cm}$ ). The work of dyeing occupied three women for one week. Twenty pounds was the maximum amount of yarn dyed in a ten-day period observed during the nine months - from September of 1999 to May of 2000 - during which the fieldwork was conducted (C. Davis, personal communication, Modesto 2001). While we have no doubt that natural dyes are used by Proyecto Típica, due to the infrequency of the dye preparation during the fieldwork, it is doubtful that all of the textiles produced by Proyecto Típica are in fact only naturally dyed. Carmen reported using some 2500 pounds of yarn a year for the textile production, a reasonable amount considering the number of artisans working for her. The dyeing of 2500 pounds of yarn, at a maximum productivity of 20 pounds per week would involve a minimum of 125 weeks of intensive dye preparation activity (i.e. over two years). Moreover, as discussed below, textile marketing takes up a large amount of Carmen's time and efforts.

\section{The Production of Naturally Dyed Textiles}

Carmen invests her own capital and credit for the materials required for textile production. Once the threads are dyed, Carmen provides them to the artisans along with a textile sample that specifies the colours and patterns to be used - directions that are to be strictly followed by the artisan. The samples follow order specifications or are created by Carmen. She assigns different artisans - based on their skills - to warp, weave, stitch the textile panels, or finish the fringes.

Artisans return the product of their work to Carmen, who pays them on a wage basis. On average, artisans receive from one to five Quetzales per day (compared with 10 to 25 Quetzales in agriculture wages), depending on the task to which they are assigned and on the amount of hours they can spend on their activity - a period often limited due to other household responsibilities. The finished textiles are sold by Carmen, who is the only one in the group aware of the prices paid for the textiles.

\section{The Commercialization of Naturally Dyed Textiles}

Carmen consigns the majority of Proyecto Típica textiles in two high-end Antigua stores, but also consigns textiles in a "fair trade" store in Quetzaltenango. Although in the past the international fair trade federation certified this store, sales last year were very sparse due to the withdrawal of international support and many internal organizational problems. The prices paid for the craft products, in fact, were similar to those offered by high-end stores. Carmen also sells textiles, of inferior quality for cheaper prices, directly to tourists or stores in Panajachel. While all the stores Carmen consigns to are aware that the textiles have been naturally dyed, the textiles being produced by Proyecto Típica are not subjected to any certification program that could guarantee their naturally dyed qualities. The high-end retail stores where textiles are consigned in Antigua sell textiles for prices that vary from 70 to 80 per cent higher than what Carmen is paid. High-end stores, concerned with textile quality and aware of the low colourfast qualities of some of the threads available to artisans, test the textiles for their colourfastness. The prices at which these stores were selling the naturally dyed textiles were relatively similar to the prices of non-naturally dyed textiles of high quality. At these stores, the naturally dyed textiles were not properly advertised such that tourists might notice that they were naturally dyed. Moreover, textiles of inferior quality but similar appearance were being sold to tourists on the street for similar prices to those charged by Carmen for her consigned textiles, and were competing with Proyecto Típica production. On the street, where retailers are more concerned with offering lower prices than with offering high-quality products, textiles of similar appearance but lower quality were offered to tourists as naturally dyed products.

Sales trips take up much of Carmen's time and efforts. Carmen travels twice a week to Panajachel, and at least every second week to Quetzaltenango and Antigua. These bus trips represent entire days away from home, and each includes up to 10 hours on a rough road inside a school bus. Transport costs vary from 20 Quetzales for a trip to Panajachel, to 30 Quetzales for a trip to Antigua - and Carmen's sales trips do not always cover even the transportation costs. On these trips, she takes new textiles to retailers, gets paid and accesses materials needed for the textile production. While piece-workers get paid a small, secure wage for their efforts in producing the pieces, the returns of Carmen and her daughter-in-law - for collecting and processing the natural dyes - depend on the sale of the final product, which can take indeterminate periods of time. 
The raw thread costs, at 10 Quetzales a pound, were found to be the largest expense in the textile production. The material and wage costs for the naturally dyed threads were estimated at an average of 17 Quetzales a pound, a price higher than that of available industrially dyed thread and synthetic dyes found in the market. This estimated cost for the naturally dyed thread took into account the thread costs, dye material costs, travel to access dyes, firewood, and collector wages. The sale of Proyecto Típica textiles, when material and wage expenses are considered, leaves Carmen with a return of 16 to 126 Quetzales per piece, and her profit margins varied from 22 to 52 per cent of the sales price. From this profit margin, Carmen still has to cover travel expenses and contribute some to her daughter-in-law for her efforts in preparing the natural dyes. What is left will represent Carmen's compensation for her efforts in the dye production, access to materials and sales trips. Piece-workers' wages consume 15 to 26 per cent of the price received by Carmen for the textiles. Material costs regularly represent more than twice the cost Carmen spends on wages. Often, Carmen has to wait lengthy periods of time before she receives any return on her investments.

\section{Discussion}

The revival of natural dyeing techniques has been associated with ecologically sustainable practices by those who promote these techniques due to the utilization of traditional knowledge, renewable dye resources (as opposed to fossil fuels), and local materials (as opposed to imports) (Aageson 1999, Hill 1986, Littrell \& Dickson 1999). As of the year 2000, the extraction of native plant materials in San Juan for the production of dyes was still limited. Native dye plants are more likely to be endangered by the expansion of coffee plantations or by their alternative uses as fuelwood, than by harvesting for dye preparation. Alternatively, the use of native trees for dye preparation could create additional returns for those who would preserve native dye plants on their property. The expansion of a market for dye plant material could give additional incentives to the landowners to preserve and/or cultivate the species used for dye purposes, but at the same time it could increase the pressure on the dye plant species found in communal land.

In Proyecto Típica, as with the other local artisan groups in San Juan, a strict division of labour among the artisans characterizes the production organization. The efforts of the warpers, weavers, and stitchers in Proyecto Típica illustrate the alienation of the weavers from the complete production process and the final use of the textiles produced, even though the traditional backstrap loom and the household settings still characterize the textile production. For their efforts in Proyecto Típica these artisans receive a wage that is sometimes as low as 15 per cent of the textile's final price, and less than half of the ma- terial costs. This fact ensures the artisans' dependency on an entrepreneur or a textile project, which can provide them with raw materials and the security of a piece wage. The artisans in Proyecto Típica maximize the returns from their activity by developing strong ties with their patron, so the patron can be relied upon to provide not only a wage, but also some security in the event of an emergency. The returns received by the artisans differ depending on the tasks to which they were assigned. Weavers assigned to the warping of yarns receive more prestige for their work, since this is associated with the determination of the final textile pattern. In contrast to Proyecto Típica's president, the artisans producing the textiles do not have contact with those who value and buy the products of their efforts. Therefore, they do not receive prestige, build self-esteem, or learn about market demands and how to expand their networks with outsiders.

The adoption of natural dyeing techniques by Proyecto Típica does not benefit all artisans in the group in similar ways. Due to the strict division of labour in Proyecto Típica, pieceworkers are excluded from all activities related to the dyeing process. Variations in the sales price do not affect artisans' wages. Technological knowledge, when concentrated in the hands of dominant groups, can reinforce hierarchical structures (Gregory \& Altman 1989). The revival of the production of naturally dyed textiles by Proyecto Típica is a response by its president to international consumer demands for natural dyes. While industrially dyed cotton yarns are easily accessible (to anyone with capital) in local stores, the production of naturally dyed yarns requires knowledge about the dye sources and techniques, and the ability to travel to access dye materials. Furthermore, in order to invest in the production of naturally dyed textiles, knowledge of specific market channels is required. These additional factors are likely to limit the revival of these techniques to more wealthy artisans (Jopling 1971). As stated by Sillitoe (1998), "The privileging of some knowledge over others will extend a degree of power to those who hold that knowledge; alternatively, making it widely known may undermine the position of its holders". This paper documents how, in Proyecto Típica, knowledge reinforces the concentration of power in the hands of the president.

The motivation for the president of Proyecto Típica to use natural dyes was a desire to differentiate the group's textiles, increase the textile quality and improve earnings as was the situation in case studies from Mexico (Morris 1991) and Turkey (Anderson 1998). Carmen, besides having the potential to earn higher cash returns than other artisans, enjoys a high level of prestige and recognition for her unique natural dyeing skills. Her natural dyeing skills have also facilitated networking with outside individuals and agencies. On the other hand, Proyecto Típica pieceworkers were using naturally dyed yarns simply because this was the kind of yarn the president provided them with. All artisans from Proyecto Típica considered 


\section{Modesto \& Niessen - The Revival of Traditional Practices as a Response to Outsiders' Demands: Resurgence of natural dye use in San Juan La Laguna}

naturally dyed yarns a high quality of yarn for tourist products, and some of them also associated the use of natural dyes with a better market and higher returns. The returns from their work in the production of naturally dyed textiles are restricted to their piece-wages, which were still low, but better than those for artisans producing lower-quality textiles in town.

The Mayan women of the group interviewed preferred bright colours over the earth tones produced with natural dyes, for their household use and clothing, as was also noted by Morris (1991) in Mexico. Although considered a good option for the production of tourist textiles, naturally dyed yarns were not believed to be suitable for household use. In this sense, the use of natural dyes illustrates the asymmetrical power between consumer and artisan (Moreno 1995, Price 1986). While the use of natural dyes has been promoted as a way to revive the indigenous ethnic tradition (Anderson 1998, Morris 1991), and adopted in an attempt to increase textile quality, the production of naturally dyed textiles does not reflect indigenous personal preferences. In promoting naturally dyed textiles as an expression of ethnic tradition, despite the fact that these textiles are not adopted by the indigenous artisans, the construction of a fictitious indigenous lifestyle (Rosenbaum \& Goldin 1997) is undertaken based on the past, rather than reflecting the dynamic context of modern indigenous life.

Proyecto Típica's practices in accessing, preparing and using natural dyes proved to be precarious, and not consistent with the volume of textiles this group produces annually. Expanding on the case study presented herein, if one individual was to dye the yarns and produce the textiles, in a best-case scenario this artisan would need to dye yarns for one full week to produce enough material to weave single-colour textiles for the rest of the month. This is the case because a vast amount of additional labour is required to produce naturally dyed textiles, including accessing the dye materials, processing these materials and dyeing the yarns.

To financially justify the production and promotion of natural dye use, sales prices should be sufficient to cover the additional efforts involved in the preparation of natural dyes. The cost of naturally dyed yarn is higher than other market alternatives available, due largely to the additional labour required in the dye preparation. However, it is difficult to find alternative high-quality industrial yarn that will ensure that textiles may be sold in high-end stores. While Proyecto Típica's textiles are sold for higher prices through high-end textile stores, the consignment prices are not higher than the prices of other textiles not naturally dyed but also considered of high quality.

The focus on the promotion of a technique such as natural dyeing, without identifying a specific market for the product, is a particular problem for indigenous artisans who are not likely to be able to create a specific market nor affect consumer demand on their own (Dickson \& Littrell 1998). Although a market for naturally dyed textiles is reported to exist by those promoting its use (Aageson 1999, Hill 1996), the Guatemalan scenario suggests that tourists are not willing to pay the additional costs involved in the production of such textiles.

\section{Conclusion}

In this paper we have described the artisans' efforts, their returns, and their motivations for participating in weavers' groups and for using natural dyes. Natural dyes are used in San Juan La Laguna to differentiate textile quality, a fact that can help to increase the competitiveness of goods when natural dye use is limited to a few artisans. The additional work required to produce naturally dyed textiles can also be a limiting factor because the additional labour receives relatively low remuneration. Furthermore, only a few artisans control the knowledge about natural dyeing techniques. Artisans need a fair market return for the extra effort required to make and use natural dyes, but such a market does not exist in Guatemala. As a result, not many artisans are motivated to produce naturally dyed textiles. The use of natural dyes by Proyecto Típica allows the group to sell their textiles through high-end retail stores that provide better returns than other retailers. However, naturally dyed textiles do not command prices higher than those of other textiles sold at the high-end stores. In order to be noticed and desired by tourists, naturally dyed textiles also require that extra efforts and resources be invested in marketing. Artisans, who already dedicate additional effort to the production of naturally dyed textiles, have neither the time nor the capital to create a special market for these products. Moreover, without some kind of certification, artisans who decide to dedicate extra effort to produce naturally dyed textiles face competition from the market of fakes posing as naturally dyed textiles. By making naturally dyed textiles to meet tourists' tastes, rather than expressing their own preferences, artisans reinforce the principle of the market economy in which "the social good is the sum of individual wants" (Costanza et al. 1997).

The political context of the organization dedicated to the production of naturally dyed textiles is a key aspect in determining who benefits from the use of natural dyes in Proyecto Típica. The adoption of natural dyeing techniques by Proyecto Típica does not benefit all artisans in the group in similar ways. In addition, secrecy has been shown to be an important tool in maintaining the exclusiveness of natural dye use and in avoiding competition. The research data shows that natural dye knowledge can be used as a power tool when it is kept secret; secrecy can limit the number of artisans who use such techniques; and this, in turn, reduces the use of dye-material and market competition. As well, the revival of natural dye use re- 
inforces the control kept by dominant groups. This study shows how the intervention of organizations engaged in diffusing traditional technical knowledge and practices, such as natural dyeing, could potentially impact the power of those who hold the traditional knowledge.

Although the purpose of this study was not to focus on the impact caused by the use of natural dyes on the physical environment, it is clear that this practice - depending on its proportions - may endanger native wild plants used as dyes. Davis (2000) noted the precarious production of natural dyes in San Juan, and determined that dye-plant extraction could add further pressure to the physical environment surrounding San Juan. This paper reveals the fragility of the Guatemalan market concerning naturally dyed textiles. It is the unattractiveness of the naturally dyed textile market that has limited the number of artisans who adopt natural dyes, and has kept this specific market niche less competitive than the ordinary textile market. The fact that low remuneration and additional effort to use natural dyes do not prevent all artisans from using these techniques reflects the economic insecurity faced by the Guatemalan artisans. Moreover, because only a few artisans have mastered natural dyeing techniques, prestige is an important incentive. Further research is suggested below on the impacts brought about by natural dye use in Guatemala.

\section{Recommendations for Further Research}

While this study has been undertaken from a holistic perspective, there are still many aspects to the revival of natural dyes in relation to the social, economic, cultural and physical environments that invite further investigation. The production of naturally dyed products by indigenous groups searching for income-raising alternatives requires a fair market and a strategy to reach such a market. Market research evaluating the existence of a fair market for the naturally dyed products, and the development of participatory strategies through which the artisans could reach the market, would assist artisans and development organizations in promoting the revival of natural dyes. The health impacts on artisans involved in the production of natural dyes are unknown. Further research is needed to determine these health consequences. The present study was mostly limited to the investigation of one group (Proyecto Típica) involved in the production of naturally dyed products. The political structure of the group was found to influence which member artisans were able to benefit from the use of natural dyes. By conducting research with other groups that use natural dyes, where the natural dye knowledge is shared amongst the group and where the members are not involved in such a hierarchical structure, important comparative information would be generated. In order to evaluate future hazardous impacts on the physical environment by the use of natural dyes, further research is required to determine the proportion of dye plants used and environmental resilience relative to their use. In order for artisans to use wild sources of dye plants without having negative impacts on the environment, further research to evaluate the potential of domestic dye-plant cultivation is required. Such research could also facilitate the task of accessing dye sources by the artisans using such materials.

Recommendations for Development Organizations, Individuals and Institutional Groups Working with Artisans Any organization, institution or individual assisting artisan groups in hopes of promoting equal benefits for all artisans should recognize the hierarchical differentiation that might exist in these groups. Despite their good intentions, anyone providing aid to artisan groups assuming that the member artisans are economically equal, and that the aid will be shared equally, could further increase differentiation among the membership.

We argue that, before promoting the use of natural dyes, fair markets for naturally dyed products should be sought. Efforts to create certification for naturally dyed textiles may improve sales and inspire trust in the consumer. Whenever promoting natural-dyes skills training, if the aim is to benefit the entire artisan group, the training should not be provided exclusively to the group leaders - in order to avoid reinforcing the hierarchical system.

Special attention should be paid to accessing local dye source materials, and consideration given to the impact that the use of wild dye plants can have on the environment. By cultivating wild dye plants, the effort expended in accessing these dye sources could be reduced, and the potential negative impacts on the physical environment could be minimised.

\section{Acknowledgements}

We would like to thank the artisans from San Juan who shared their knowledge and lives with us, and the Canadian International Development Agency (CIDA) for the financial assistance. We are thankful to Kelsey Nelson and Cristiana Seixas for their valuable comments.

\section{Literature Cited}

Aageson, T.H. 1999. Indigenous artisan and sustainable development in Latin America and the Caribbean. Second OAS/ World Bank Working Meeting on Cultural Heritage Partnership. Washington (DC) www.aid2artisans. org/docs/ATANews/spring99/BaseFrame.htm.

Anderson, J. 1998. Return to Tradition: The revitalization of Turkish Village Carpets. University Press, Washington.

Antweiler, C. 1998. Local knowledge and local knowing: An anthropological analysis of contested "cultural prod- 


\section{Modesto \& Niessen - The Revival of Traditional Practices as a Response to Outsiders' Demands: Resurgence of natural dye use in San Juan La Laguna}

ucts" in the context of development. Anthropos 93:469494.

Buchanan, R. 1990. Mordant safety. Brooklyn Botanic Garden Record 46:89-91.

Carlsen, R.S. \& D.A. Wenger. 1991. The dyes used in Guatemalan textiles: A diachronic approach. Pp. 359-380 in Textile traditions of Mesoamerica and the Andes. Edited by M.B. Schevill, J.C. Berlo \& E.B. Bwyer. Garland, New York.

Costanza R., J. Cumberland, H. Daly, R. Goodland \& N. Norgaard. 1997. An Introduction to Ecological Economics. St. Lucie Press, Boca Raton, Florida.

Dalby, G. 1990. Dyeing, dyes and the environment. Journal for Weavers, Spinners and Dyers 154 (April):12-13.

Davis, C.E. 2000. A Human Ecological Consideration of Natural Dyes and Dyeing in San Juan la Laguna, Guatemala. M.S. thesis, University of Alberta, Edmonton, Alberta.

Dickinson, M.A. \& M.A. Littrel. 1998. Organizational Culture for Small Textile and Apparel Business in Guatemala. Clothes and Textile Research Journal 16(2):68-78.

Ehlers, T.B. 1993. Belts, business and bloomingdale's: An alternative model for Guatemalan artisan development. Pp. 180-196 in Crafts and the World Market. Edited by J. Nash. State University of New York Press, New York.

Gould, K., A.F. Howard \& G. Rodriguez. 1998. Sustainable production of non-timber forest products: Natural dye extration from El Cruce dos Aguadas, Peten, Guatemala. Forest Ecology and Management 111:69-82.

Gregory, C.A. \& J.C. Altman.1989. Observing the Economy. Routledge, London, U.K.

Hendrickson, C. 1997. Imagenes del Maya en Guatemala el papel del traje indigena en las construcciones del indigena y del latino. Mesoamerica 33:15-40.

Hermitte E. 1972. Ponchos, weaving, and patron-client relations in northwest Argentina. Pp. 159-174 in Structure and Process in Latin America: Patronage, clientage and power systems. Edited by A. Strickton \& S.M. Greenfield. University of New Mexico Press, Albuquerque, New Mexico.

Hill, D. 1996. Is there a future for natural dyes? Society of Dyers and Colourists 45(2):1-8.

Jopling, C.F. 1975. Yalálag weaving: Its aesthetic, technological and economic nexus. Pp. 211-236 in Material Culture: Styles, organization, and dynamics of technology: Proceedings of the American Ethnographical Society.
Edited by H. Lechtman \& R. Merrill. West Publishing, St, Paul, Minnesota.

Lara, F.G. 1988. Situación actual del uso de colorantes naturales en la artesania Guatemalteca. Subcentro Regional de Artesanias Populares, Guatemala, California.

Littrell, M.A. \& M.A. Dickson. 1999. Social responsibility in the Global Market: Fair trade of cultural products. Sage, Thousand Oaks, California.

Lopez, L.L. 1997. Diagnostico del Municipio de San Juan La Laguna, Departamento de Solalá, Guatemala, Central America. Fundacion Centroamericana de Desarrollo, Guatemalla.

LWDP/WAYANG. 1995. Weaving for Alternatives!. Nutcha, Bangkok, Thailand.

Modesto, H.S. 2001. The Socio-economic Impact of Weaving and Naturally Dyed Textile Production in San Juan la Laguna, Guatemala. M.S. thesis. University of Alberta, Edmonton, Alberta.

Moreno, J. \& M. Littrell. 1998. Guatemalan textile and apparel: Acquisition and production in a global market. Pp. 11-17 in Softgoods to the World. Edited by P. Hokes, L. Good \& P. Huddleston. International Textile and Appalrel Association Monograph \#9.

Moreno, J. M. 1995. Retailers as Interpreters of Textile Traditions in Antigua, Guatemala. Ph.D. dissertation, Iowa State University, Ames, lowa.

Morris, W.F. Jr. 1991. The marketing of Mayan textiles in Highland Chiapas, Mexico. Pp. 403-433 in Textile Traditions of Mesoamerica and the Andes: An anthology. Edited by M.B. Schevill, J.C. Berlo \& E.B. Dwyer. Garland, New York.

Nash, J. 1993. Introduction: Traditional arts and changing markets in Middle America. Pp. 1-22 in Craft in the World Market. Edited by J. Nash. State University of New York, Albany, New York.

Niessen, S. 1996. Asian Examples of Craft in Trade: The social, the cultural, and the unsustainable. Unpublished manuscript, University of Alberta, Edmonton, Alberta.

Orellana, S.L. 1984. The Tzutujil Mayas. University of Oklahoma, Norman, Oklahoma.

Price, S. 1986. Primitive art in civilized places. Art in Americas January:9-13.

Racanog, V. 1997. Socioeconomia Maya Precolonial. Cholsamag, Guatemala. 
Reiche, O. \& J.M.A. Itzep. 1999. Manual de Tintes Naturals. PROSIGUA, PROART/CEDART, PRODETOTO, Guatemala City, C.A.

Rosenbaum, B. \& L.R. Goldin. 1997. New exchange process in the international market: the re-marketing of Mayan artisan production in Guatemala. Museum Anthropology 21:72-82.

Rouanet, F.R. 1989. Enero-Junio. Causas de la tranformación y estinción de las artesanias en Guatemala. Folklore Americano 47:179-192.

Sillitoe, P. 1998. The development of indigenous knowledge: a new applied anthropology. Current Anthroplogy 39:223-252.

Swetnam, J. 1989. What else did Indians have to do with their time? Alternatives to labor migration in pre-Revolutionary Guatemala. Economic Development and Cultural Change 38:89-112.

The Software Toolworks. 1993. The Software Toolworks World Atlas MPC Version 4.0.1. [CD-ROM]. The Software Toolworks, Novato, California.

UNDP. n.d.. United National Development Program. The small-scale textile production using natural dyes. In Sharing Innovative Experiences: www.undp.org/tcdc/index2. 